\title{
Development of Inward Currents in Chick Sensory and Autonomic Neuronal Precursor Cells in Culture
}

\author{
K. Gottmann, I. D. Dietzel, H. D. Lux, S. Huck, and H. Rohrer ${ }^{1}$ \\ Department of Neurophysiology and 'Department of Neurochemistry, Max Planck Institute for Psychiatry, D-8033 Planegg- \\ Martinsried, FRG
}

The development of ionic inward currents was studied in cultured neuronal precursors from chick sensory dorsal root ganglia (DRG) and compared with neuronal precursors from the cholinergic ciliary ganglia (CG) using whole cell patchclamp recording. Neuronal precursors devoid of neuron-specific surface markers were isolated during the period of neuronal birth, i.e., at embryonic day ( $E$ ) 6 from DRG and at E4.5 from CG. All neuronal precursor cells from DRG, as well as $\mathrm{CG}$, showed outward $\mathrm{K}^{+}$currents directly after they had attached to the substrate.

During the first $5 \mathrm{hr}$ in culture, half of the DRG cells had no inward currents at all, whereas the other half displayed a rapidly and fully inactivating $\mathrm{Ca}^{2+}$ current, which was activated with small depolarizing pulses from a holding potential of $-80 \mathrm{mV}$ to a $-\mathbf{5 0} \mathrm{mV}$ membrane potential (low-voltage-activated current, LVA). At these early stages, no other inward currents were resolved. TTX-blockable $\mathrm{Na}^{+}$currents and slowly inactivating classical $\mathrm{Ca}^{2+}$ currents, which were activated with larger depolarizing pulses to a $-20 \mathrm{mV}$ membrane potential (high-voltage-activated currents, HVA) appeared concurrently after 15-20 hr in culture.

In contrast, more than half of the CG cells showed LVA currents, as well as $\mathrm{Na}^{+}$currents, as early as during the first $5 \mathrm{hr}$ in culture. The HVA $\mathrm{Ca}^{2+}$ currents from the majority of the cells could be recorded only after 10-15 hr in culture.

In both types of precursor-derived neurons, the LVA $\mathrm{Ca}^{2+}$ current preceded the classical HVA $\mathrm{Ca}^{2+}$ current. However, the temporal relation of the first $\mathrm{Na}^{+}$currents to the first HVA $\mathrm{Ca}^{2+}$ currents seemed to be different in the 2 preparations. In DRG cells, $\mathrm{Na}^{+}$and HVA $\mathrm{Ca}^{2+}$ currents appeared at the same time, whereas in CG cells, the HVA $\mathrm{Ca}^{2+}$ current showed a time lag with respect to the $\mathrm{Na}^{+}$current. In addition, the relative amplitudes of the currents differed in the $C G$ and DRG cells. This shows that as early as E4-6, shortly after

\footnotetext{
Received Aug. 3, 1987; revised Nov. 20, 1987; accepted Feb. 2, 1988.

This work was supported by Grants SFB $220 \mathrm{Al}$ and A8 of the Deutsche Forschungsgemeinschaft. For data evaluation, the flexible programs, INTES $v$ and AUTES v, written by $H$. Zucker, were used. T. El-Sharkawy participated in some earlier experiments. We are indebted to $\mathrm{H}$. Thoenen for helpful discussions, and R. Grantyn for valuable comments on the manuscript. We want to thank V. Bulka, L. Stegmann, and E. Schroeder for technical assistance.

Correspondence should be addressed to K. Gottmann, Max Planck Institute for Psychiatry, Dept. of Neurophysiology, Am Klopferspitz 18A, D-8033 PlaneggMartinried, FRG.

${ }^{a}$ Present address: Department of Neuropharmacology, University of Vienna, A-1090 Vienna, Austria.

Copyright (C) 1988 Society for Neuroscience $0270-6474 / 88 / 103722-11 \$ 02.00 / 0$
}

their terminal mitosis, neurons from distinct peripheral ganglia in chick vary in the development of their basic ionic currents.

During development, neurons differentiate into populations with different functions, reflected by diverse transmitter contents, receptors, and morphology. Neurons also differ with respect to the shapes of their action potentials, which are brought about by the interplay of several inward and outward ionic currents. During differentiation of the various subtypes of neurons, it is conceivable that the ionic currents develop stereotypically, forming a "basic neuron," which then further differentiates. Alternatively, early differences between neuronal precursors could cause variations in the development of the first ionic currents.

The first investigations of developing neurons suggested that the fast $\mathrm{Na}^{+}$-dominated action potential is developmentally preceded by longer lasting $\mathrm{Ca}^{2+}$-dependent potential changes (Spitzer, 1979). However, an analysis investigating the development of isolated currents in a related species, using voltageclamp methods, suggested that both $\mathrm{Na}^{\prime}$ and $\mathrm{Ca}^{21}$ currents were already present at the earliest stages at which neurons could be morphologicaly identified. The maturation of the spike thus seemed to be due to an increase in the relative proportion of outward currents that later suppressed $\mathrm{Ca}^{2+}$-dominated action potentials of longer duration (Barish, 1986). Hence, it is not sufficient to analyze action potential waveforms in order to study the sequence of appearance of the different ionic currents. For such studies, the ionic currents have to be separated under voltage-clamp conditions. Investigations of this type have, thus far, been carried out in cell cultures from avian neural crest (Bader et al., 1983), in precursor cells from chick dorsal root ganglia (DRG) (Rohrer et al., 1985), and in a mouse teratocarcinoma cell line (Simonneau et al., 1985). In all 3 preparations, outward currents carried by $\mathrm{K}^{+}$were already present. The first inward current that could be measured in DRG as well as teratocarcinoma cells was a rapidly inactivating $\mathrm{Ca}^{2+}$ current. This type of $\mathrm{Ca}^{2+}$ current was activated from a holding potential of $-80 \mathrm{mV}$, using small depolarizing pulses, to $-50 \mathrm{mV}$ (LVA current; Carbone and $\mathrm{Lux}, 1984$ ). The appearance of $\mathrm{Na}^{+}$and classical $\mathrm{Ca}^{2+}$ currents, which inactivated more slowly and were activated with larger depolarizing pulses to $-20 \mathrm{mV}$ (HVA current), was observed in close succession in neural crest, as well as DRG, cells.

The concern of the present investigation was to find out whether the succession, $\mathrm{K}^{+}$current $>\mathrm{LVA} \mathrm{Ca}{ }^{2+}$ current $>\mathrm{Na}^{+}$current and HVA $\mathrm{Ca}^{2+}$ current, could be generalized for neurons that later form ganglia with different functions within the same 
Table 1. Internal and external solutions used for the isolation of $\mathrm{Na}^{+}$and $\mathrm{Ca}^{21}$ currents ${ }^{u}$

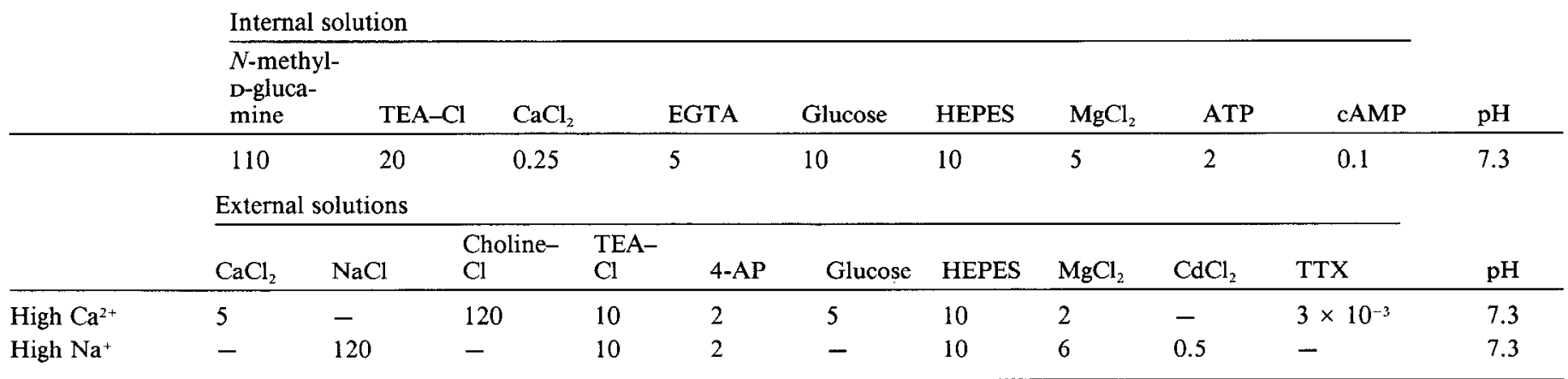

a All concentrations are given in mM.

species. The neurons of peripheral ganglia are generated over a period of several days. During this period, these ganglia always contain a mixture of immature and mature cells, such that undifferentiated cells are difficult to distinguish. This problem was solved by eliminating the more differentiated neurons from the population by complement-mediated cell lysis (Rohrer et al., 1985). This method allowed us to isolate, during the period of neuronal birth, populations of immature neuronal precursor cells from DRG at E6, as well as ciliary ganglia (CG) at E4.5 (Rohrer and Thoenen, 1987), which are in comparable stages of differentiation. Using whole cell patch-clamp recordings, it was then possible to compare the development of early $\mathrm{Ca}^{2+}$ and $\mathrm{Na}^{+}$currents in precursor-derived neurons from a sensory and an autonomic ganglion.

\section{Materials and Methods}

Cell preparation and culture. DRG were removed from 6-d-old chick embryos. To avoid contamination by sympathetic ganglia, DRG were taken only from lumbosacral levels, and the tissues ventral to the DRG were carcfully ablated. Ciliary ganglia were removed from 4.5-d-old chick embryos. Ganglia were collected in PBS supplemented with $1 \mathrm{mg}$ $\mathrm{ml}$ glucose. DRG and ciliary ganglia were then treated with $0.1 \%$ trypsin for 6 or $10 \mathrm{~min}$, respectively. Trypsinization was stopped by adding soybean trypsin inhibitor $(0.1 \%)$. After washing with Ham's F14 medium, supplemented with $10 \%$ horse serum and $5 \%$ fetal calf serum, the ganglia were washed twice with F14 supplemented with BSA ( $1 \mathrm{mg}$ ) $\mathrm{ml}$ ) and then dissociated to single cells by trituration. To remove differentiated neurons and glial cells, the cell suspension from DRG was treated with the monoclonal antibodies Q211 and 04 in the presence of agarose-treated guinea pig complement, as described previously (Rohrer et al., 1985, 1986). Precursor cells from ciliary ganglia survived better in the presence of glial cells. Therefore, only neurons were eliminated by Q211-killing from ciliary ganglion cell suspensions. After the complement-mediated cell lysis, the remaining cells were collected by centrifugation and resuspended in F14 medium. To remove cell debris resulting from the killing procedure, the cell suspension was carefully layered onto a $3 \% \mathrm{BSA} / \mathrm{F} 14$ solution and centrifuged for $25 \mathrm{~min}$ at 60 $\times g$ (Ernsberger and Rohrer, 1988). This resulted in an almost complete separation of lysed and nonlysed cells. More than $95 \%$ of intact cells were recovered in the pellet. The cells were suspended and cultured in F14 medium supplemented with $10 \%$ horse serum and $5 \%$ fetal calf serum. In addition, $\mathrm{NGF}(20 \mathrm{ng} / \mathrm{ml})$ or ciliary neurotrophic factor (CNTF; $10 \mathrm{ng} / \mathrm{ml}$ ) was present as a survival factor in DRG or CG cultures, respectively. NGF was prepared from mouse salivary gland according to Suda et al. (1978); CNTF was prepared from rat sciatic nerve according to Manthorpe et al. (1986) (the generous gift of M. Sendtner). The cells were plated onto polyornithine-coated dishes $(0.5 \mathrm{mg} / \mathrm{ml})$ that had also been treated with mouse sarcoma laminin (BRL; $10 \mu \mathrm{g} / \mathrm{nl}$ ) for at least $2 \mathrm{hr}$ (Edgar et al., 1981).

Recording conditions. After 20-30 hr in culture, precursor-derived neurons demonstrated typical neuronal morphology (Fig. 1, B, D). After $1-10 \mathrm{hr}$ in culture, the precursor-derived neurons could be clearly dis- tinguished from glial precursors or fibroblasts by their characteristic shape (smooth surface, short processes of uniform diameter, phasebright cell bodies for DRG, and phase-dark cell bodies for early CG cells; see Fig. 1, A, C). The identification of immature neurons by morphological criteria was initially confirmed by staining the cultures with antibodies against the Q211 antigen, which is rapidly expressed by neuronal precursor cells in culture. Membrane currents in precursorderived neurons were measured using patch-clamp recording in a whole cell configuration (Hamill et al., 1981). Pipettes were made of Duran glass (Schott Ruhrglass; Mainz, FRG) with a 2-step pulling procedure ("Mecanex" Puller; Geneva). After they were filled with the internal solution listed in Table 1 , their resistances varied between 5 and 10 $\mathrm{M} \Omega$. $\mathrm{Na}^{+}$and $\mathrm{Ca}^{2+}$ currents were isolated using the external solutions shown in Table 1. The solutions were applied from perfusion pipettes similar to the onc described by Carbonc and Lux (1987). Recordings were performed at $20-22^{\circ} \mathrm{C}$ on the stage of an inverted phase-contrast microscope. In most experiments, data were directly digitized at 3.0 $\mathrm{kHz}$ for $\mathrm{Ca}^{2+}$ currents and $7 \mathrm{kHz}$ for $\mathrm{Na}^{+}$currents with an LSI $11 / 73$ computer. Capacitative transients were minimized by analog circuitry. Leakage and capacitative artifacts were further reduced by subtracting the averaged and appropriately scaled responses of the cell to hyperpolarizing pulses from the currents elicited by depolarizing test pulses.

\section{Results}

\section{Inward currents in $D R G$ precursor-derived neurons}

$\mathrm{Na}^{+}$currents. One hour after plating, the cells had attached to the substrate and precursor-derived neurons could be identified by their characteristic morphology (see Fig. 1 and Materials and Methods). These cells could then be analyzed for ionic currents in whole cell clamp configuration. $\mathrm{Na}^{+}$currents were recorded in the high- $\mathrm{Na}^{+}$solution listed in Table 1. Ionic currents through $\mathrm{Ca}^{2+}$ channels had been blocked by $0.5 \mathrm{mM} \mathrm{Cd}^{2+}$ (which blocks $\mathrm{Ca}^{2+}$ currents in precursor cells; see below) and $\mathrm{K}^{+}$currents blocked by 4 -AP and tetraethylammonium (TEA) in the external solution. $\mathrm{K}^{+}$currents had been further reduced by adding TEA to the $\mathrm{K}^{+}$-free internal solution. After establishing a seal and breaking the membrane, several minutes were allowed for the equilibration of the pipette solution with the cell interior. By this time, the outward currents, which are already present in cultures of this age (Rohrer et al., 1985), were abolished. The cells were held at $-80 \mathrm{mV}$ and $\mathrm{Na}^{+}$currents were elicited with depolarizing potential steps applied for $50 \mathrm{msec}$.

In cells maintained in culture for less than $10 \mathrm{hr}$, no $\mathrm{Na}^{+}$ currents could be recorded under the above conditions in any of the 35 cells investigated (Fig. 2B). After 15-20 hr in culture, very fast inactivating inward currents could be detected in $44 \%$ of the cells $(n=18)$. They activated at membrane potentials of about $-40 \mathrm{mV}$ and reached peak amplitudes at about $-10 \mathrm{mV}$. Time to peak decreased with increasing step potentials (Fig. 
$1-10 \mathrm{hr}$
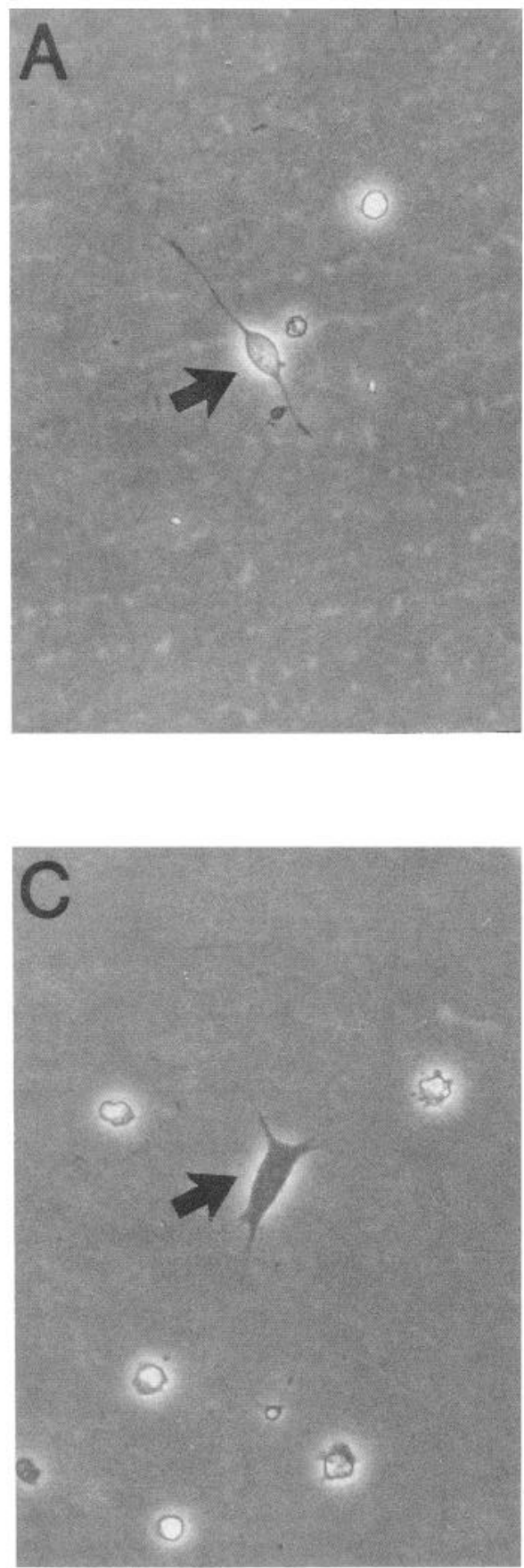

$20-30 \mathrm{hr}$
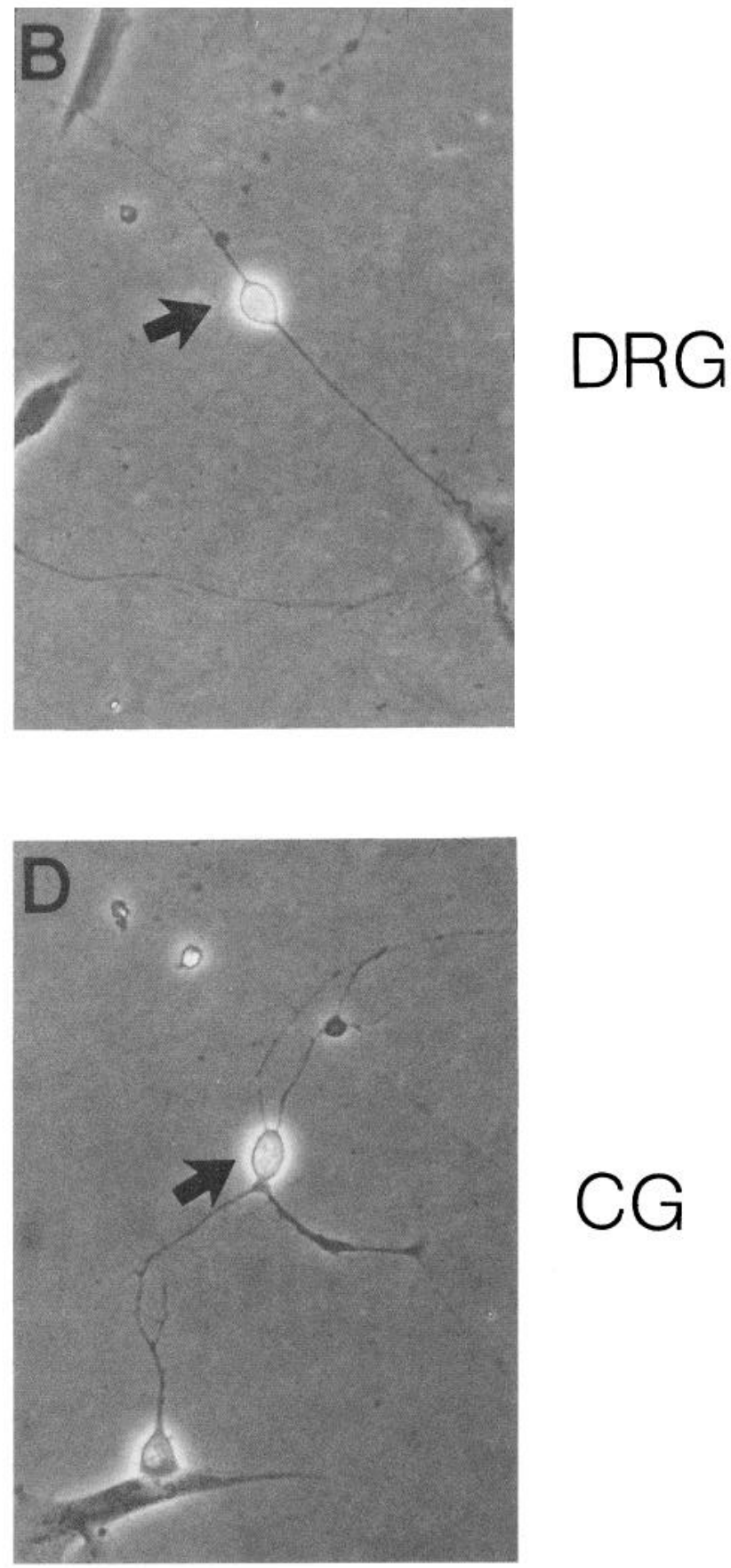

CG

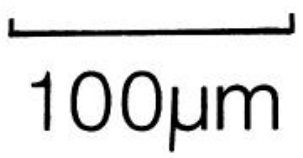

Figure 1. Morphology of typical precursor-derived neurons from dorsal root ganglia (DRG) and ciliary ganglia (CG). A, B, Cells from DRG between 1 and 10 and 20 and $30 \mathrm{hr}$ in culture. $C, D$, Cells from CG between 1 and 10 and 20 and $30 \mathrm{hr}$ in culture. 


\section{DRG cells}

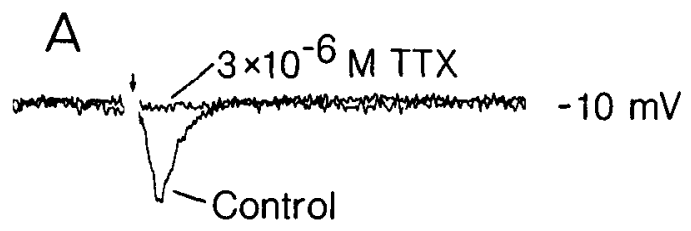

$1-10 \mathrm{hr}$

$20-30 \mathrm{hr}$
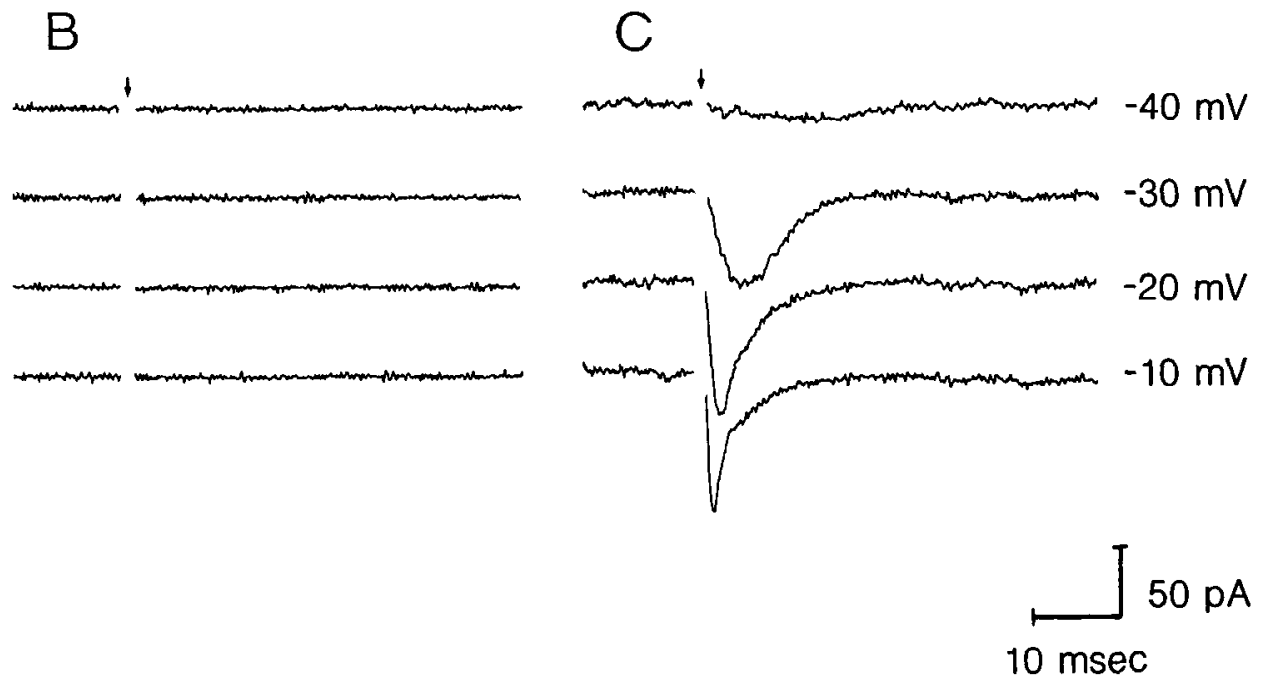

1- $10 \mathrm{hr}$ DRG cell

A

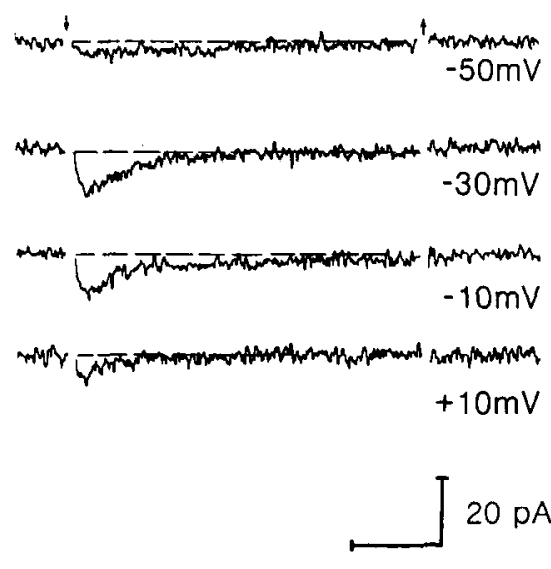

$50 \mathrm{msec}$

C

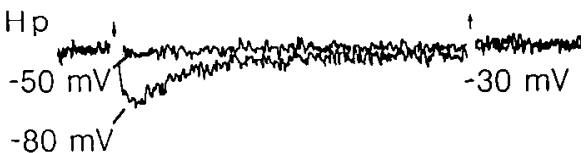

B

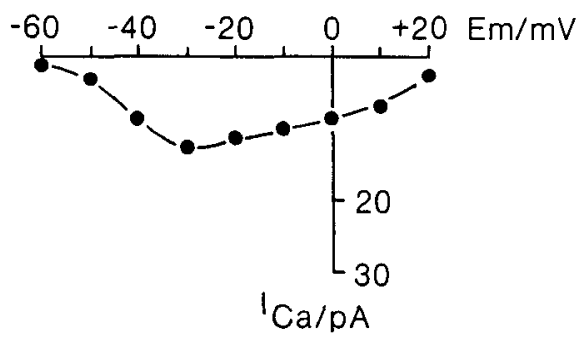

Figure 2. $\mathrm{Na}^{+}$currents in precursorderived neurons from DRG. External solution, $120 \mathrm{mM} \mathrm{Na}^{+}$(Table 1). Holding potential, $-80 \mathrm{mV}$. Cells were stepdepolarized to various membrane potentials at times indicated by arrows. A, Cell (after 20-30 hr in culture) was depolarized from 80 to $10 \mathrm{mV}$ with and without addition of $3 \times 10^{-6} \mathrm{M}$ TTX to external solution. $B, C$, Currents elicited by a series of step depolarizations, as indicated in the margin, typical for cells cultured for $1-10$ versus 20-30 hr.
Figure 3. $\mathrm{Ca}^{2+}$ currents in dorsal root precursor-derived ncurons, typical for a 1-10 hr culture. External solution, 5 mM Ca${ }^{2+}$ (Table 1). Holding potential, $-80 \mathrm{mV}$. $A$, Cell was step-depolarized for $200 \mathrm{msec}$ (indicated by arrows) to the potentials shown at right. $B$, Peak amplitudes of the current versus potential for cell shown in $A$. C, Cell was stepdepolarized to $-30 \mathrm{mV}$ from holding potentials of -50 and $-80 \mathrm{mV}$. Note that no current was elicited when the cell was held at potentials more depolarized than $-50 \mathrm{mV}$. $D$, Cell was depolarized to $-30 \mathrm{mV}$ with and without addition of $0.5 \mathrm{~mm} \mathrm{Cd}^{2+}$ to external solution. 
A

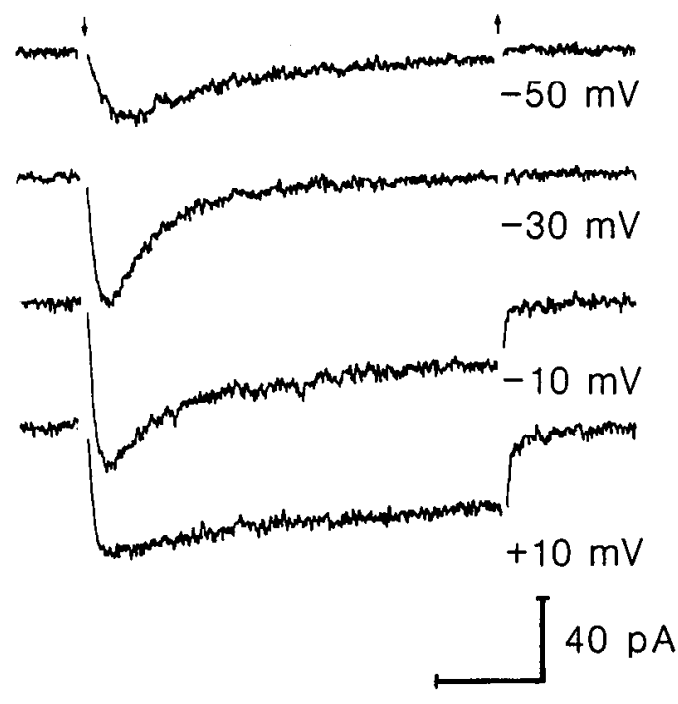

$50 \mathrm{msec}$

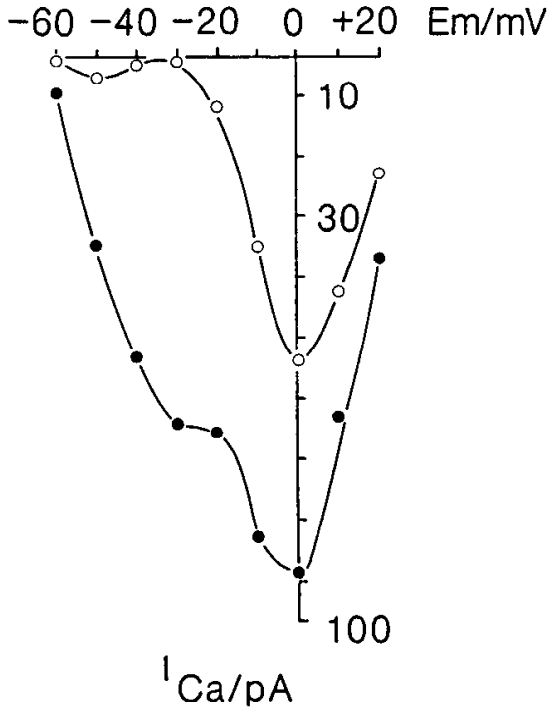

${ }^{\mathrm{I}} \mathrm{Ca} / \mathrm{pA}$
Figure 4. $\mathrm{Ca}^{2+}$ currents in a dorsal root precursor-derived neuron, typical for a $25-30 \mathrm{hr}$ culture. Holding potential, $-80 \mathrm{mV}$. External solution, $5 \mathrm{~mm} \mathrm{Ca}^{2+}$ (Table 1). $A$, Cell was step-depolarized for $200 \mathrm{msec}$ (indicated by arrows) to membrane potentials shown at right. Note the persistent $\mathrm{Ca}^{2+}$ current component activated at potentials more depolarized than $-30 \mathrm{mV}$. $B$, Peak current (filled circles) and current after 200 cell (open circles) versus voltage. Same $\mathrm{V}$ characteristic.

$2 C$ ). In all cells investigated, this current could be fully blocked by $3 \times 10^{-6} \mathrm{M}$ TTX in the external solution (Fig. 2A). This means that the TTX binding site was functional as soon as voltage-dependent $\mathrm{Na}^{+}$currents could be recorded. The properties of these currents were similar to those of the $\mathrm{Na}^{+}$currents described in differentiated DRG cells (Carbone and Lux, 1986). The population of cells showing such inward currents increased with time in culture, reaching $90 \%$ of the neurons after $25-30$ hr $(n=21)$. Simultaneously, the amplitude of the current increased and could reach as much as $200 \mathrm{pA}$ at $-10 \mathrm{mV}$ membrane potential after $30 \mathrm{hr}$ in culture.

$\mathrm{Ca}^{2+}$ currents. $\mathrm{Ca}^{2+}$ currents were measured in the high-Ca ${ }^{2+}$

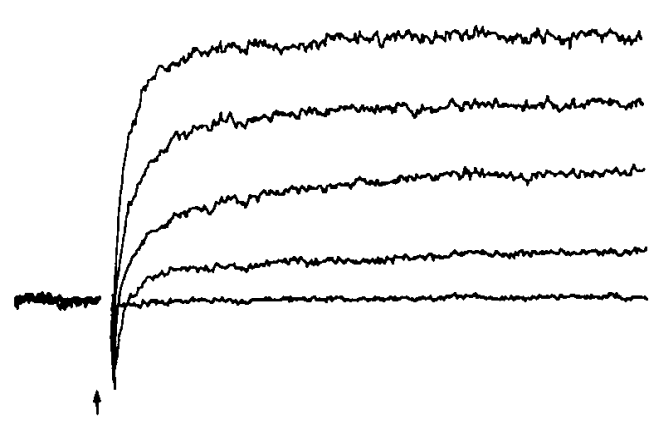

$+40 \mathrm{mV}$ $+20 \mathrm{mV}$ $0 \mathrm{mV}$ $-20 \mathrm{mV}$ $-40 \mathrm{mV}$

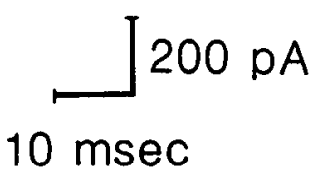

Figure 5. Inward and outward currents in a precursor-derived neuron from CG, typical for a $1-5 \mathrm{hr}$ culture. External solution, culture medium (F14). Pipette solution, $150 \mathrm{~mm} \mathrm{KCl,} 0.25 \mathrm{~mm} \mathrm{CaCl}_{2}, 5 \mathrm{~mm}$ EGTA; 10 mu glucose, $10 \mathrm{~mm}$ HEPES, $\mathrm{pH}$ 7.3. Holding potential, $-80 \mathrm{mV}$. Cell was step-depolarized to various membrane potentials at time indicated by arrow. solution listed in Table 1. Currents through $\mathrm{Na}^{+}$channels had been blocked by adding TTX to the external solution and substituting choline for $\mathrm{Na}^{+}$. To reduce the rundown of calcium currents, the pipette solution contained cAMP, ATP, and $\mathrm{Mg}^{2+}$ (Kostyuk et al., 1981). Using this precaution, rapid washout of $\mathrm{Ca}^{2+}$ currents was not seen. Test pulses to various membrane potentials from a holding potential of $-80 \mathrm{mV}$ were applied for $200 \mathrm{msec}$.

In agreement with the observations of Rohrer et al. (1985), in the first $5 \mathrm{hr}$ after plating, small, rapidly inactivating $\mathrm{Ca}^{2+}$ currents were elicited in $54 \%$ of the cells after depolarizing steps to membrane potentials more positive than $-50 \mathrm{mV}(n=26)$. The currents reached maximum amplitudes between -30 and $-20 \mathrm{mV}$ (Fig. $3 B$ ), and inactivated completely within $100 \mathrm{msec}$ (Fig. 3A). The amplitude was strongly dependent on the holding potential. No currents were elicited if the cell was held at potentials positive to $-50 \mathrm{mV}$ (Fig. 3C). At any time in culture, these currents were almost completely blocked by $0.5 \mathrm{mM} \mathrm{Cd}^{2+}$ in the external solution (Fig. 3D). All the properties of this $\mathrm{Ca}^{2+}$ current that were investigated corresponded to the properties of the low voltage activated $\mathrm{Ca}^{2+}$ current (LVA current) described in more differentiated cells from DRG (Carbone and Lux, 1984; Bossu et al., 1985; Fedulova et al., 1985; Nowycky et al., 1985). After about $15 \mathrm{hr}$, of 68 cells investigated, 67 showed this current (Fig. 10). The amplitude of this current increased with time in culture. While the maximal current of a cell recorded after $1-5 \mathrm{hr}$ in culture was $12 \mathrm{pA}$ at a membrane potential of $-30 \mathrm{mV}$, up to $60 \mathrm{pA}$ could be recorded after 25$30 \mathrm{hr}$.

After $15-20 \mathrm{hr}$, in $41 \%$ of the 17 cells investigated, a persistent $\mathrm{Ca}^{2+}$ current component appeared when the membrane was depolariced to membrane potentials more positive than -30 $\mathrm{mV}$ (Fig. 4A). The corresponding peak current-membrane potential relationship shows a second peak with a maximal inward current at slightly more depolarized membrane potentials (Fig. 


\section{CG cells}
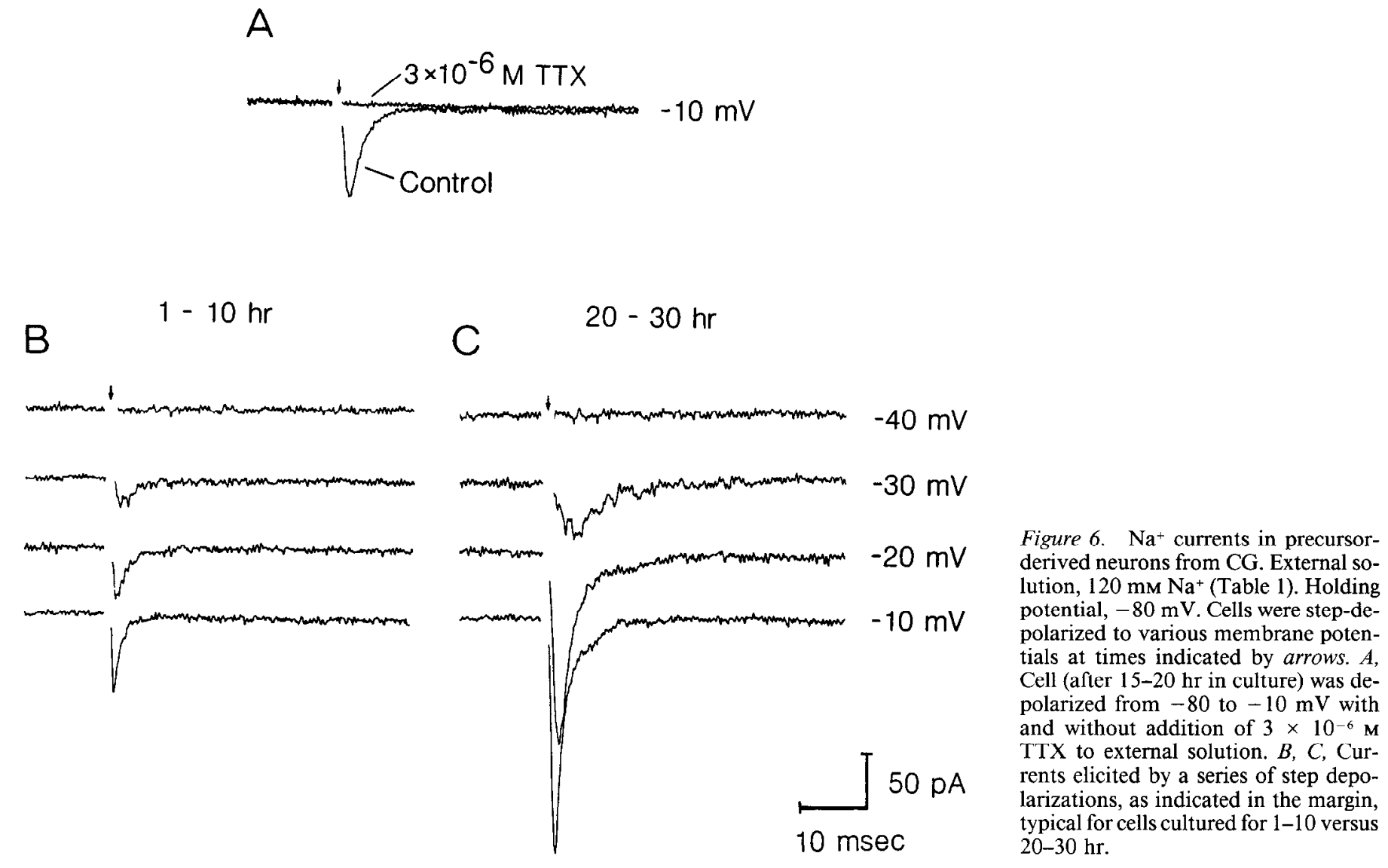

$4 B$ ). The persistent component of the $\mathrm{Ca}^{2+}$ currents reached maximal amplitude at $0 \mathrm{mV}$ membrane potential. The slow inactivation of these currents and the shape of the currentmembrane potential relationship indicate the presence of the classical $\mathrm{Ca}^{2+}$ current, which is activated at higher membrane potentials (HVA current) than the LVA current. With increasing time in culture, a greater proportion of cells showed this current (Fig. 10). The first persistent $\mathrm{Ca}^{2+}$ currents were measured after about $15 \mathrm{hr}$, and between 25 and $30 \mathrm{hr}$, they were recorded in $85 \%$ of the population $(n=20)$. As with the $\mathrm{Na}^{+}$current, the maximal amplitude of this current at $-10 \mathrm{mV}$ membranc potential rose with time, with up to $70 \mathrm{pA}$ being recorded between 25 and $30 \mathrm{hr}$ in culture. As shown in Figure 10, the $\mathrm{Na}^{+}$and $\mathrm{HVA} \mathrm{Ca}^{2+}$ currents developed about simultaneously, following the LVA current with a time delay of approximately $15 \mathrm{hr}$.

Whether the increase in HVA Ca ${ }^{2+}$ currents is related to neurite sprouting was intensively investigated in freshly dissociated DRG cells. The HVA current was always present in freshly dissociated, mature neurons, in contrast to the precursor-derived neurons studied within the first hours. Neurites in the process of sprouting contribute little to the total $\mathrm{Ca}^{2+}$ current in a pheochromocytoma cell line (PC12), or in mature DRG cells. This was observed by exposing somatic and neuritic membrane regions to different external $\mathrm{Ca}^{2+}$ using a laminar flow system with sharp $(20 \mu \mathrm{m})$ boundaries (Streit and Lux, 1988).

Although cells cultured up to $30 \mathrm{hr}$ have neurites of about $150 \mu \mathrm{m}$ in length, the majority of the cells could be adequately clamped. By exposing different membrane regions to different
$\mathrm{Ca}^{2+}$ concentrations, Streit and Lux (1988) recorded currents from growth cones and neurites that showed kinetics and voltage dependences similar to those measured from the somatic membrane. Using cable equations, they estimated that the potential of the neuritic membrane deviates by about $5 \%$ from the soma at the end of neurites $2 \mu \mathrm{m}$ in diameter and $150 \mu \mathrm{m}$ in length.

DRG neuronal precursor cells, but not CG precursor cells, could be cultured in the absence of 04-positive glial cells. In order to compare the results observed in both types of cells, DRG precursor cells were also grown under the conditions used for ciliary precursor cclls, i.c., in the presence of 04-positive glial cells. In these experiments, neither $\mathrm{Na}^{+}$nor $\mathrm{HVA} \mathrm{Ca}{ }^{2+}$ currents could be recorded in the first $10 \mathrm{hr}$ in culture. Thus, the succession of appearance of ionic currents was independent of the number of glial cells in the culture dish.

\section{Ionic currents in precursor-derived neurons from the $C G$}

To find out whether this sequence of developinent of the basic inward currents is ubiquitous in chick peripheral neurons, we repeated our analysis with precursor cells from another chick ganglion, the autonomous CG. E4.5 CG also contain a population of neuronal precursors that has not yet expressed the Q211 antigen, allowing the preparation of analogous cultures (Rohrer and Thoenen, 1987).

Like DRG cells, all investigated CG cells showed outward currents by the time the cells had sufficiently attached to the substrate. Outward currents could be blocked by removing intracellular $\mathrm{K}^{+}$and by the internal addition of TEA, indicating 
$1-5$ hr CG cell

A

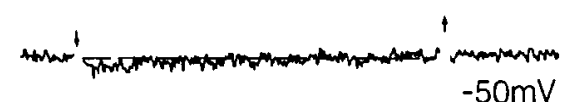

$-30 \mathrm{mV}$

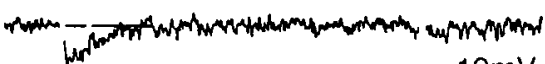

$-10 m \mathrm{~m}$

Figure 7. $\mathrm{Ca}^{2+}$ currents in ciliary precursor-derived neurons, typical for a $1-$ $5 \mathrm{hr}$ culture. External solution, $5 \mathrm{~mm}$ $\mathrm{Ca}^{2+}$ (Table 1). Holding potential, -80 $\mathrm{mV}$. $A$, Cell was step-depolarized for $200 \mathrm{msec}$ (indicated by arrows) to the potentials shown at right. $B$, Peak amplitudes of the current versus potential for cell shown in $A$. $C$, Cell was stepdepolarized to $-30 \mathrm{mV}$ from holding potentials of -50 and $-80 \mathrm{mV}$. Note that no current was elicited when the cell was held at potentials more depolarized than $-50 \mathrm{mV} . D$, Cell was depolarized to $-30 \mathrm{mV}$ with and without addition of $0.5 \mathrm{mM} \mathrm{Cd}^{2+}$ to external solution.
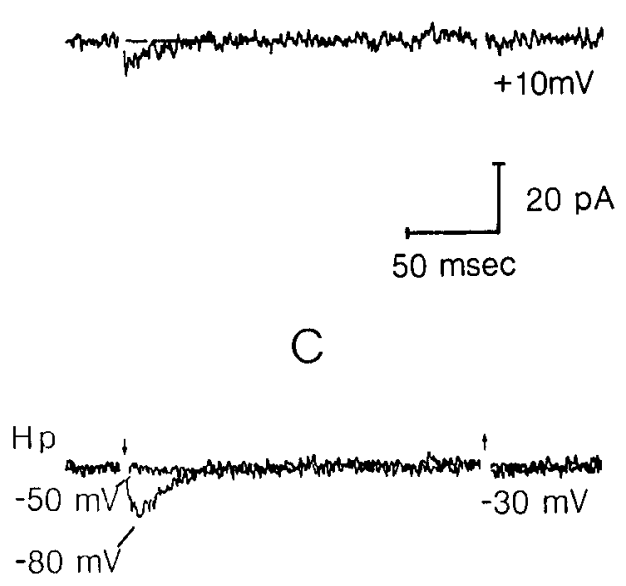

B
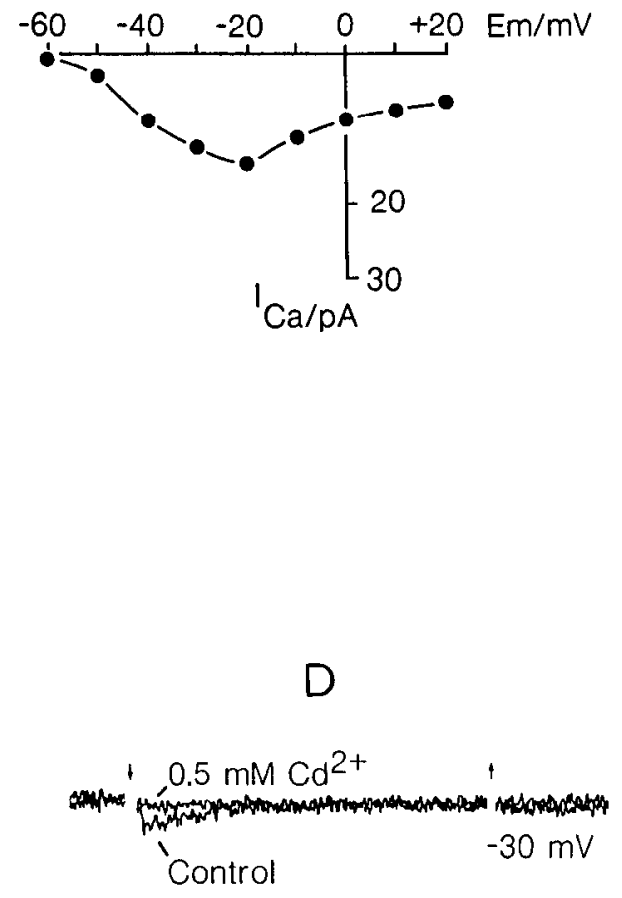

that they were carried by $\mathrm{K}^{+}$(see also Bader et al., 1983). In contrast to recordings from DRG neurons, fast inward currents could already be measured in most cells after less than $5 \mathrm{hr}$ in culture (Fig. 5).

$\mathrm{Na}^{+}$currents. Using the high- $\mathrm{Na}^{+}$solution (Table 1), we already observed very fast inactivating inward currents in $73 \%$ of the cells cultured for less than $5 \mathrm{hr}(n=11)$ (Figs. 6B, 10). These $\mathrm{Na}^{+}$currents resembled those of DRG cells with respect to kinetics and voltage dependence. After $10 \mathrm{hr}$ in culture, 24 out of 25 cells recorded showed these inward currents (Fig. 10). Within $30 \mathrm{hr}$, the maximal amplitude recorded in any of the cells increased from $50 \mathrm{pA}$ at $-10 \mathrm{mV}$ membrane potential in the first $5 \mathrm{hr}$ to $290 \mathrm{pA}$ between 20 and $30 \mathrm{hr}$ (see Fig. 6, B, C). As in DRG cells, these currents were totally blocked by $3 \times$ $10^{-6} \mathrm{M}$ TTX in the external solution (Fig. 6A).

$\mathrm{Ca}^{2+}$ currents. A total of $73 \%$ of the cells recorded between 1 and $5 \mathrm{hr}$ in culture also showed a small, rapidly inactivating current in the high- $\mathrm{Ca}^{2+}$ solution $(n=11)$ (Fig. $7 A$ ). This current inactivated within $100 \mathrm{msec}$ and reached maximal amplitude at membrane potentials of about $-20 \mathrm{mV}$ (Fig. 7 B). As in DRG cells, it could be blocked with $0.5 \mathrm{mM} \mathrm{Cd}^{2+}$ (Fig. 7D) and could not be activated when the membrane was held at potentials more depolarized than $-50 \mathrm{mV}$ (Fig. $7 \mathrm{C}$ ). The amplitude of the LVA current in CG cells increased less with time in culture than it did in DRG cells. At $1-5 \mathrm{hr}$, the cell with the maximal current at $-30 \mathrm{mV}$ reached $12 \mathrm{pA}$, as in DRG cells. After 25$30 \mathrm{hr}$, the maximal current was, however, only $23 \mathrm{pA}$. Likewise, the average amplitude of the inactivating current component increased less in CG than in DRG cells (see Fig. 11).

After more than $10 \mathrm{hr}$ in culturc, 27 out of 30 cells recorded displayed an additional persistent $\mathrm{Ca}^{2+}$ current component. This component showed kinetics and voltage dependence similar to that of the persistent component in DRG precursor-derived neurons (Fig. 8). The maximal persistent current component increased from $9 \mathrm{pA}$ at $-10 \mathrm{mV}$ membrane potential at $1-5 \mathrm{hr}$ to $70 \mathrm{pA}$ at $25-30 \mathrm{hr}$, which was also the maximal value measured in DRG cells at this time.

As was recorded in DRG neurons (Boll and Lux, 1985), in $\mathrm{CG}$ precursor-derived neurons, the persistent component of the $\mathrm{Ca}^{2+}$ current was more sensitive to the organic calcium channel blocker Verapamil than the inactivating component was. While $500 \mu \mathrm{M}$ of Verapamil completely abolished all $\mathrm{Ca}^{2+}$ currents (not shown), 250 $\mu \mathrm{M}$ blocked predominantly the persistent component (Fig. $8 D$ ). Starting from more depolarized holding potentials, the inactivating component at $-30 \mathrm{mV}$ membrane potential was more suppressed than the persistent component (Fig. $8 C$ ). In all aspects investigated, $\mathrm{Ca}^{2+}$ currents in $\mathrm{CG}$ precursorderived neurons had properties similar to those of DRG cells.

If one assumes that $\mathrm{HVA} \mathrm{Ca}^{2+}$ channels are predominantly localized on neurites, it could be argued that the late appearance of the HVA current in CG cells reflects the regenerating outgrowth of neurites, rather than neuronal differentiation (Yaari et al., 1987). To find out whether HVA currents are strongly reduced in freshly dissociated preparations of differentiated cells from $\mathrm{CG}$ as well, $\mathrm{Ca}^{2+}$ currents were recorded after $1-5 \mathrm{hr}$ in cultures of E8 CG. Although these cells had only very short neurites after a few hours in culture (Fig. 9), comparable in length to the neurite-like processes of $\mathrm{CG}$ precursor-derived neurons during the first hours in culture (Fig. 1C), HVA currents of more than $60 \mathrm{pA}$ at $-10 \mathrm{mV}$ membrane potential were recorded. Their amplitude was comparable to those of precursor cells after $30 \mathrm{hr}$ in culture, which had much longer neurites (Figs. 1D, 9). 
$25-30 \mathrm{hr}$ CG cell

A
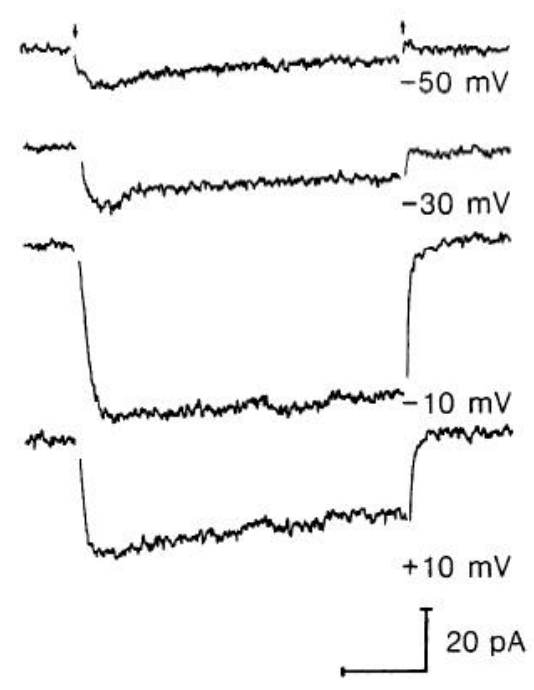

$50 \mathrm{msec}$

\section{C}

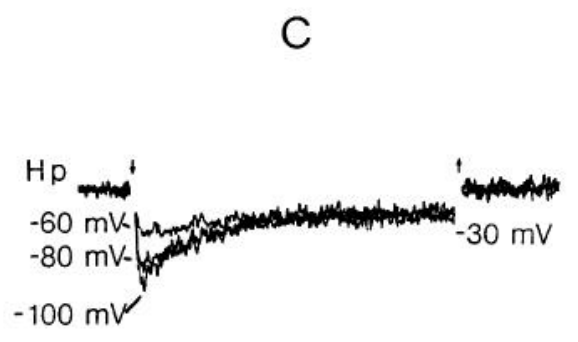

B

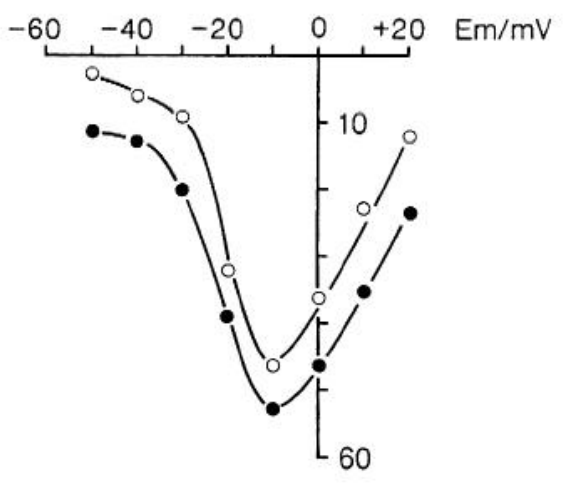

I $\mathrm{Ca} / \mathrm{pA}$

\section{E8 CG cell}

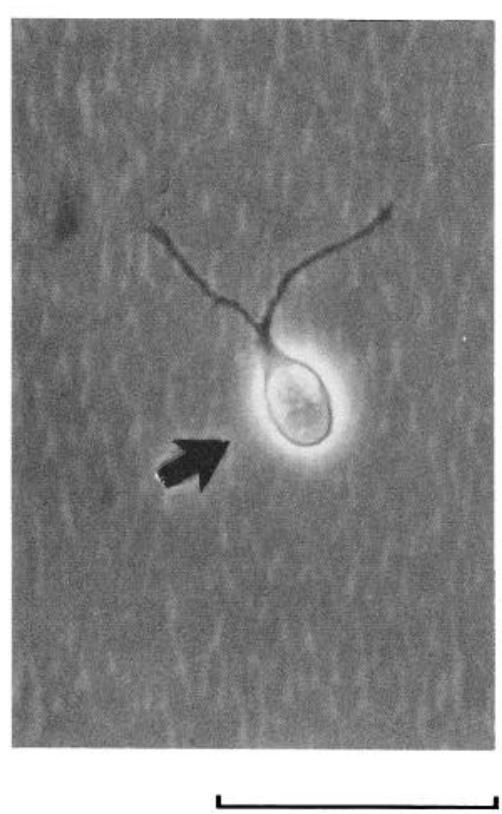

$50 \mu \mathrm{m}$

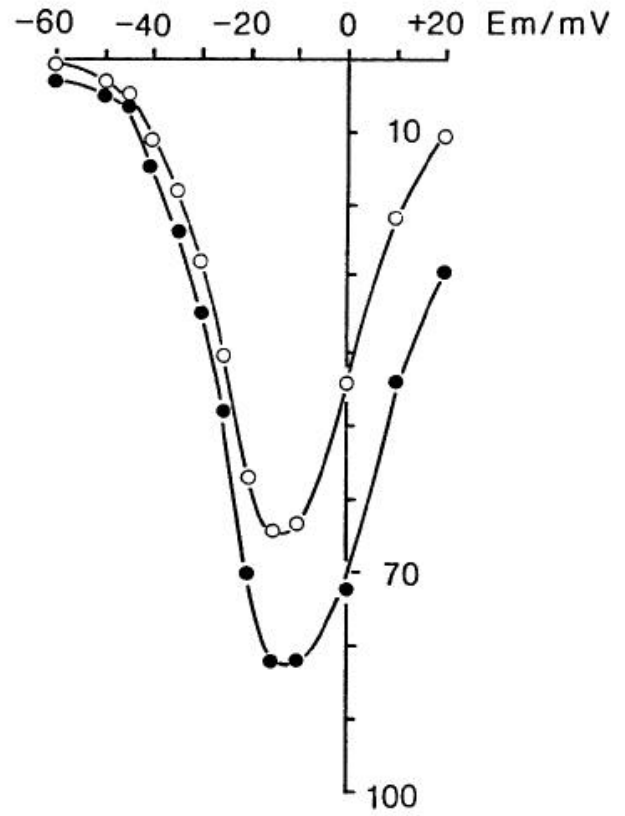

${ }^{\mathrm{I}} \mathrm{Ca} / \mathrm{pA}$
Figure 9. $\mathrm{Ca}^{2+}$ currents of a neuron from freshly dissociated CG at E8. $A$, Morphology of a typical cell after $1 \mathrm{hr}$ in culture. $B$, Peak current (filled circles) and current after $200 \mathrm{msec}$ (open circles) of cell shown in $A$. External solution, $5 \mathrm{~mm} \mathrm{Ca}^{2+}$ (Table 1). Holding potential, $-80 \mathrm{mV}$. Note that this current-membrane potential relationship rather compares to that of a precursor cell after 25-30 hr in culture (Fig. 8). 

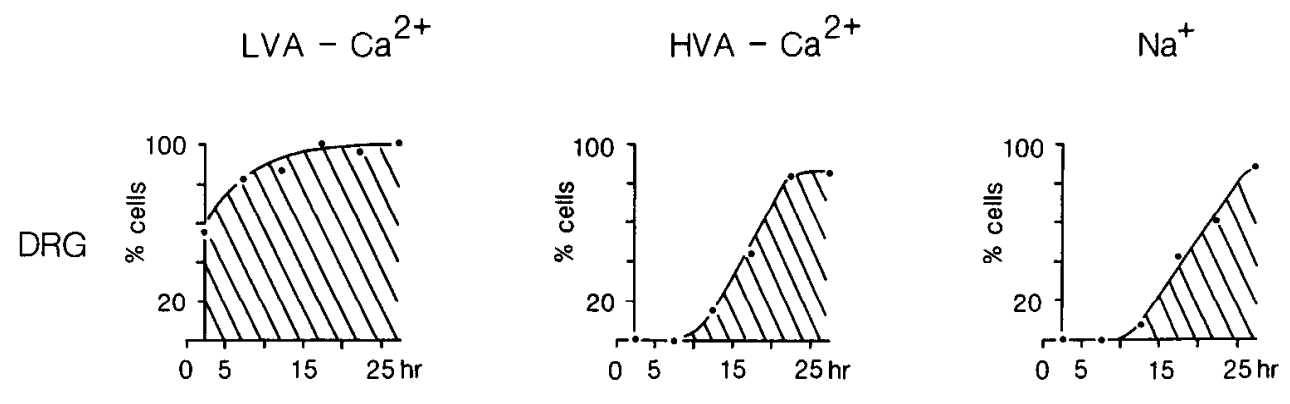

Figure 10. Summary of the appearances of the 3 inward currents versus time in culture for precursor-derived neurons from DRG and CG. For each dot, data from between 8 and 26 cells, measured within a time interval of 5 $\mathrm{hr}$, were pooled. For each time interval, the percentage of cells showing the appropriate current (detection limit, $5 \mathrm{pA}$ ) was calculated.
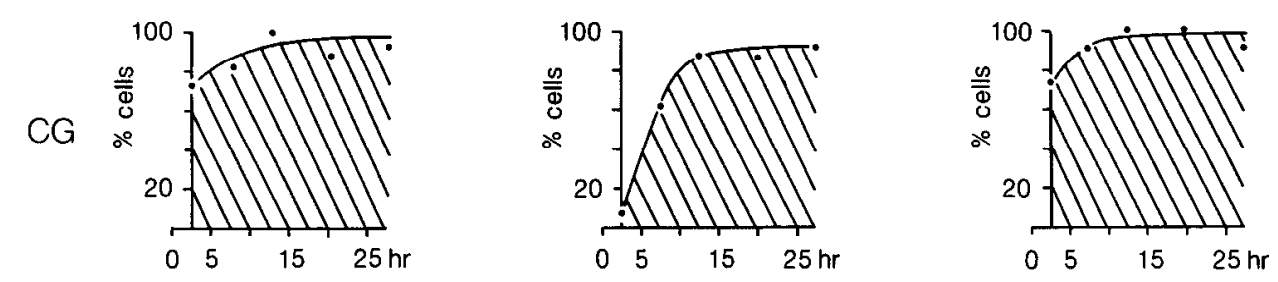

$$
\begin{array}{ll}
1-5 \mathrm{hr} & 25-30 \mathrm{hr} \\
\mathrm{Ca}^{2+} \mathrm{Ca}^{2+} \mathrm{Na}^{+} & \mathrm{Ca}^{2+} \mathrm{Ca}^{2+} \mathrm{Na}^{+} \\
\text {LVA HVA } & \text { LVA HVA }
\end{array}
$$

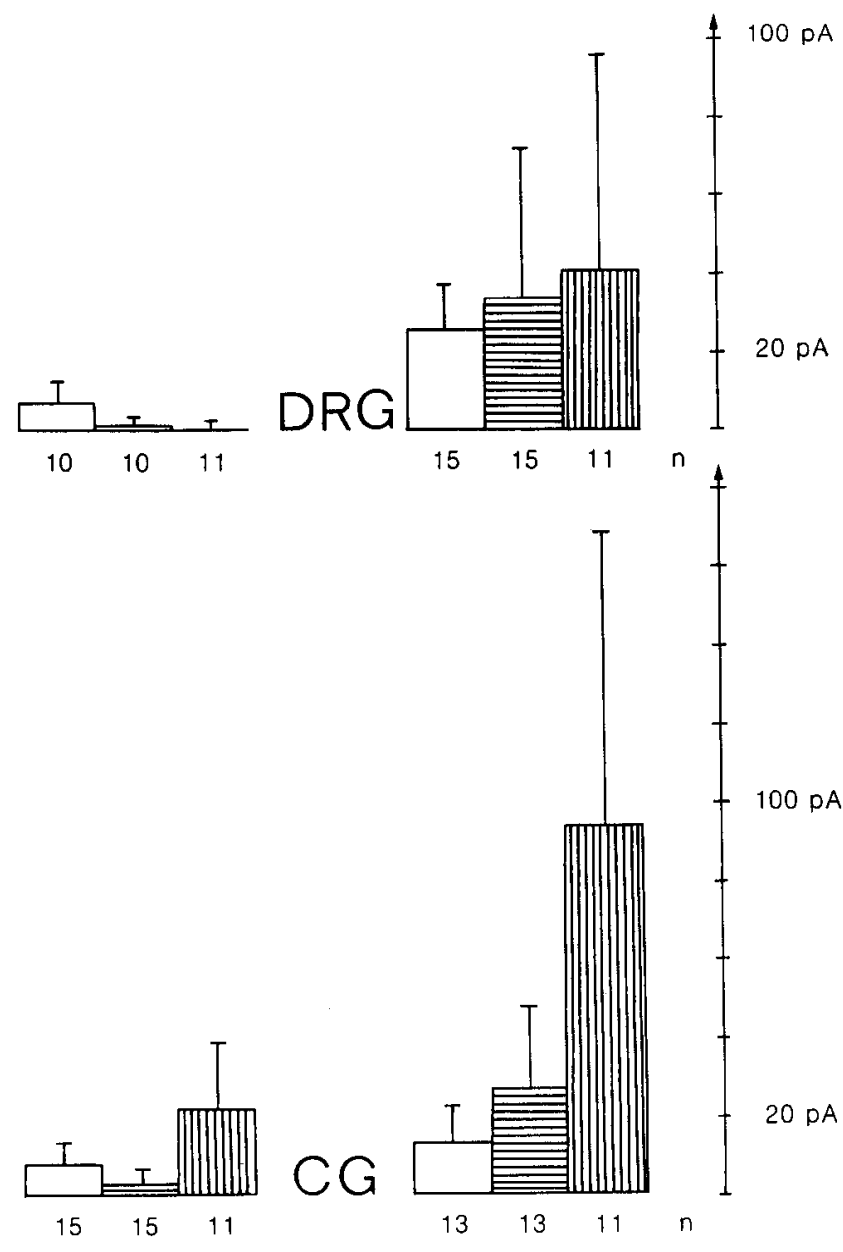

This suggests that the late development of the HVA current component reflects embryonic differentiation rather than regeneration in culture.

\section{Discussion}

Precursor cells from chick DRG have been shown to differentiate in vitro into neurons characterized by neuronal morphology, by the presence of neuron-specific markers and ion channels (Rohrer et al., 1985). During differentiation in vitro, the LVA current has been shown to appear before HVA currents could be recorded. Similar early LVA currents were observed in a mouse embryonal carcinoma cell line (Simonneau et al., 1985) and in cultures from rat hippocampus (Yaari et al., 1987). The development of an inactivating $\mathrm{Ca}^{2+}$ channel as the first inward current was also seen in Drosophila flight muscles (Salkoff, 1985). Here we report the same sequence of development of $\mathrm{Ca}^{2+}$ currents in precursor-derived neurons from chick CG. We have demonstrated that the LVA currents of CG and DRG cells had similar properties, i.e., activation only from holding potentials negative to $-50 \mathrm{mV}$, complete inactivation after $100 \mathrm{msec}$, and lower sensitivity to Verapamil than that of the HVA current.

Figure 11. Summary of the average development of current amplitudes for early and late cultures of DRG and CG precursor-derived neurons. Standard deviations are given as bars. $n$, Number of cells. The amplitudes of the $\mathrm{HVA} \mathrm{Ca}^{2+}$ currents were measured after $200 \mathrm{msec}$ of step-depolarization from -80 to $-10 \mathrm{mV}$. LVA Ca ${ }^{2+}$ current amplitudes were measured as peak amplitudes minus current after 200 $\mathrm{msec}$ for -80 to $-10 \mathrm{mV}$. Values obtained by this method differed by about $\pm 3 \mathrm{pA}$ from the peak current measured for -80 to $-30 \mathrm{mV}$ depolarizations. For calculation of the average $\mathrm{Na}^{+}$current amplitudes, the peak currents were measured for depolarizations from -80 to -10 $\mathrm{mV}$. The amplitudes of the $\mathrm{Na}^{+}$currents differed significantly for CG and DRG cells at both time intervals ( $t$ test; $p<0.01$ ). While the amplitudes of both $\mathrm{Ca}^{2+}$ currents at $1-5 \mathrm{hr}$ and $\mathrm{HVA}$ currents at 25$30 \mathrm{hr}$ could not be shown to differ significantly $(p>0.05)$, the LVA currents measured in DRG cells at $25-30 \mathrm{hr}$ were significantly larger than those in CG cells $(p<0.01)$. 
In contrast to the stereotyped sequence of development of the $\mathrm{Ca}^{2+}$ currents, the $\mathrm{Na}^{+}$currents seemed to develop on different time scales in DRG and CG precursor cells. While the HVA calcium current developed in DRG cells at about the same time as the $\mathrm{Na}^{+}$current did, the HVA current lagged behind the $\mathrm{Na}^{+}$ current in CG cells by about $5 \mathrm{hr}$ (Fig. 10). This suggests that there is no fixed time interval in which $\mathrm{Na}^{+}$and $\mathrm{HVA} \mathrm{Ca}^{2+}$ currents develop in neurons from different peripheral ganglia. An initial lack of inward currents, and $\mathrm{Na}^{+}$and $\mathrm{Ca}^{2+}$ currents appearing in close sequence have also been reported by Bader et al. (1983) in avian neural crest cells differentiating in culture. The neurons differentiating in neural crest cultures under the conditions used by these authors acquire properties of sensory neurons (Ziller et al., 1987). Their general findings are thus in agreement with our results in DRG precursors.

It may be argued that the absence of $\mathrm{HVA} \mathrm{Ca}^{2+}$ currents in small, precursor-derived neurons is due to an exaggerated washout in these small cells, which leads to a rapid loss of HVA currents. However, HVA currents were recorded in $64 \%$ of the small CG cells in culture (Fig. 10), indicating that the absence of HVA currents is not an effect of washout. $\mathrm{Ca}^{2+}$ current rundown was not observed to be particularly fast in these small cells.

From the fact that neuronal precursor cells from CG and DRG express ion channels in slightly different sequences, it can be concluded that the appearance of ion channels reflects differentiation of precursor cells, rather than recovery from dissociation. This point is also strengthened by the demonstration that neuronal precursor cells start to express other neuron-specific markers, such as the Q211 antigen, with time in culture. In addition, we showed that freshly dissociated, mature neurons from DRG (Rohrer et al., 1985) and CG (this study), which have only very short neurites, comparable in length to the processes of precursor-derived neurons during the first hours in culture, display $\mathrm{Na}^{+}$and $\mathrm{Ca}^{2+}$ currents. This finding also excludes the possibility that the late expression of HVA currents in precursor-derived neurons reflects merely the regenerative outgrowth and elongation of neurites.

The whole population of DRG cells acquired $\mathrm{Na}^{+}$as well as HVA Ca ${ }^{2+}$ currents within an interval of 10-15 hr (Fig. 10). The DRG precursor cells used in the present experiments were between 6 and $18 \mathrm{hr}$ past the terminal S-phase at the time of plating (as shown by ${ }^{3} \mathrm{H}$-thymidine labeling; see Rohrer and Thoenen, 1987). This means that the cells scattered with respect to their terminal mitosis by $12 \mathrm{hr}$. If the incorporation of ionic channels is closely linked to the time point of the last mitosis, then the appearance of a certain ionic current would show the same scatter. If the incorporation of channels is only loosely coupled to the last mitosis, then a broader distribution would be expected. If the signal for induction of the currents were given externally-for instance, by plating the cells - the time interval between the first to the last cell to express this current could have been much shorter. Our finding that the DRG cells develop $\mathrm{Na}^{+}$and HVA Ca${ }^{2+}$ currents within an interval of $10-$ $15 \mathrm{hr}$ is compatible with the hypothesis that the development of ionic currents follows the last mitosis with a fixed delay.

Both populations of precursor cells differed not only in the sequence of development of $\mathrm{Na}^{+}$versus $\mathrm{Ca}^{2+}$ currents, but also in the average amplitudes of the different currents (Fig. 11). Since the cellular populations were not closely synchronized, but displayed a scatter in their development by about $12 \mathrm{hr}$, the amplitudes recorded scatter considerably. However, data av- eraged from more than 10 cells/sample reveal characteristic differences between the 2 populations. The average amplitudes of the different currents in DRG and CG precursors after 25$30 \mathrm{hr}$ in culture can be compared because cell size and the length of neurites are comparable. The HVA current amplitudes were almost cqual in DRG and CG cells after 25-30 hr in culture, and both populations had started with similar LVA amplitudes. However, the LVA currents had increased much more in the DRG cells (Fig. 11), and the $\mathrm{Na}^{+}$currents in CG cells were larger than those in DRG cells. Hence, both populations can be distinguished shortly after their terminal mitosis not only on the basis of a different sequence of appearance of ionic channels, but also by differences in the relative amplitudes of the different currents.

It should be noted that neuronal precursor cells, both from CG and DRG, were isolated during the period of neuronal birth (E6 for DRG, E4.5 for CG) by the same procedure used to eliminate differentiated neurons, and are thus considered to be in the same stage of differentiation. Although the observation of differences during development in culture does not prove that the same differences occur during development in vivo, the observed differences in current development in culture indicate an inherent difference between CG and DRG precursors. This suggests that the precursor cells differentiating in culture have already been committed, prior to isolation, to the autonomic or sensory cell lineage. This is in agreement with other evidence for an early segregation of sensory and autonomic cell lineages obtained from transplantation experiments and from the analysis of neural crest cells differentiating in culture (Le Lièvre et al., 1980; Ziller et al., 1987).

\section{References}

Bader, C. R., D. Bertrand, E. Dupin, and A. C. Kato (1983) Development of electrical membrane properties in cultured avian neural crest. Nature 305: 808-810.

Barish, M.E. (1986) Differentiation of voltage-gated potassium current and modulation of excitability in cultured amphibian spinal neurones. J. Physiol. (Lond.) 375: 229-250.

Boll, W., and H. D. Lux (1985) Action of organic antagonists on neuronal calcium currents. Neurosci. Lett. 56: 335-339.

Bossu, J. L., A. Feltz, and J. M. Thomann (1985) Depolarization elicits two distinct calcium currents in vertebrate sensory neurons. Pfluegers Arch. 403: 360-368.

Carbone, E., and H. D. Lux (1984) A low voltage-activated calcium conductance in embryonic chick sensory neurons. Biophys. J. 46:413418.

Carbone, E., and H. D. Lux (1986) Sodium channels in cultured chick dorsal root ganglion neurons. Eur. Biophys. J. 13: 259-271.

Carbone, E., and H. D. Lux (1987) Kinetics and selectivity of a lowvoltagc-activated calcium current in chick and rat sensory ncurones. J. Physiol. (Lond.) 386: 547-570.

Edgar, D., Y. A. Barde, and H. Thoenen (1981) Subpopulations of cultured sympathetic neurons differ in their requirements for survival factors. Nature 289: 294-295.

Ernsberger, U., and H. Rohrer (1988) Neuronal precursor cells in chick dorsal root ganglia: Differentiation and survival in vitro. Dev. Biol. 126: 420-432.

Fedulova, S. A., P. G. Kostyuk, and N. S. Veselovsky (1985) Two types of calcium channels in the somatic membrane of new-born rat dorsal root ganglion neurones. J. Physiol. (Lond.) 359: 431-446.

Hamill, O. P., A. Marty, E. Neher, J. Sakmann, and I. Sigworth (1981) Improved patch clamp techniques for high-resolution current recording from cells and cell-free membrane patches. Pfluegers Arch. 391: 85-100.

Kostyuk, P. G., N. S. Veselovsky, and S. A. Fedulova (1981) Ionic currents in the somatic membrane of rat dorsal root ganglion neurons-II. Calcium currents. Neuroscience 6: 2431-2437.

Le Lièvre, C. S., G. Schweizer, C. M. Ziller, and N. M. Le Douarin 
(1980) Restrictions of developmental capabilities in neural crest cell derivatives as tested by in vivo transplantation experiments. Dev. Biol. 77: 362-378.

Manthorpe, M., S. D. Skaper, L. R. Williams, and S. Varon (1986) Purification of adult rat sciatic nerve ciliary neuronotrophic factor. Brain Res. 367: 282-286.

Nowycky, M. C., A. P. Fox, and R. W. Tsien (1985) Three types of neuronal calcium channels with different agonist sensitivity. Nature 316: 440-443.

Rohrer, H., and H. Thoenen (1987) Relationship between differentiation and terminal mitosis: Chick sensory and ciliary neurons differentiate after terminal mitosis of precursor cells, whereas sympathetic neurons continue to divide after differentiation. J. Neurosci. 7 : 3739-3748.

Rohrer, H., S. Henke-Fahle, T. El-Sharkawy, H. D. Lux, and H. Thoenen (1985) Progenitor cells from embryonic chick dorsal root ganglia differentiate in vitro to neurons: Biochemical and electrophysiological evidence. EMBO J. 4: 1709-1714.

Rohrer, H., A. L. Acheson, J. Thibault, and H. Thoenen (1986) Developmental potential of quail dorsal root ganglion cells analyzed in vitro and in vivo. J. Neurosci. 6: 2616-2624.
Salkoff, L. (1985) Development of ion channels in the flight muscles of Drosophila. J. Physiol. (Paris) 80: 275-282.

Simonneau, M., C. Distasi, L. Tauc, and C. Poujeol (1985) Development of ionic channels during mouse neuronal differentiation. J. Physiol. (Paris) 80:312-320.

Spitzer, N. C. (1979) Ion channels in development. Annu. Rev. Neurosci. 2: 363-397.

Streit, J., and H. D. Lux (1988) Calcium current distribution in PC 12 cells during NGF-induced differentiation. Pfluegers Arch. 411 Suppl. R 143.

Suda, K., Y. A. Barde, and H. Thoenen (1978) Nerve growth factor in mouse and rat serum: Correlation between bio-assay and radioimmuno-assay determinations. Proc. Natl. Acad. Sci. USA 75: 40424046.

Yaari, Y., B. Hamon, and H. D. Lux (1987) Development of two types of calcium channels in cultured mammalian hippocampal neurons. Science 235: 680-682.

Ziller, C., M. Fauquet, C. Kalcheim, J. Smith, and N. M. Le Douarin (1987) Cell lineages in peripheral nervous system ontogeny: Mediuminduced modulation of neuronal phenotypic expression in neural crest cell cultures. Dev. Biol. 120: 101-111. 